\title{
ACKNOWLEDGMENTS
}

7 his book owes its existence to the brilliant writer, editor, and historian

1 Steve Davis. He is a righteous soul who embodies the notion that creativity and selflessness are not mutually exclusive-in fact, I suspect he is so creative because he is so generous. I had stopped being a healthy skeptic a long time ago and had unfortunately trudged toward suspicious cynicismand so I wondered, at first, why Steve would be interested in my old work. What was his angle?

Meeting Steve and collaborating with him (and getting to know his wonderful family) was like embarking on a process of remembering something important, of getting reacquainted with some forgotten ideals-like dusting off tools tucked up on a shelf and putting them back on the workbench. He had no agenda other than to help resurrect some stories he thought had merit. So, it's no surprise that Steve is also the best kind of writer-curious, thoughtful, adventurous. I believe he lives life that way: he cares for Mother Texas at a deep, elemental level, exploring its rivers and its bedrock - literally, Steve, like me, treasures the plume agate from West Texas and the rare llanite, studded with blue quartz, from an enchanted part of Central Texas, and he knows these aren't just rocks he is holding in his hands ... they are so much more than that. I am lucky to have met Steve, worked with him, and benefited from his wisdom.

A special thank you to the many editors, over the years, who allowed me to pursue my work. Each of them is tied by the almost unlikely generosity they afforded me:

Ron White in San Antonio once told me that he liked me because the story we had agreed upon was never the one I eventually wrote for him. Being naïve, I thought he was being ironic, that he was mad at me. I finally got his drift—-that stories are organic, they can't be predicted before they are 
written. The first time I wrote for him, he told me to ride the interstate in Texas and just look for things. No need to fixate on what was out thereuntil you went out there. What an extraordinary editor. The journalist Beth Nissen was an early role model and mentor. She encouraged me, and I doubt I would have written a printed word if not for her. She gave me direction, some sense of purpose, and confidence. Melissa Houtte was a wonderful editor who took many chances on me, who defended me, who indulged me, who created a supportive, humane environment. Other editors I have known were products of some management-training program, or some such thing, but Melissa instinctively knew how to connect with people.

I met the fine writer Mike Geffner through the mail and phone calls, and we became close friends without meeting each other for a very long time. There are those good, joyous moments when you bond with another writer-and that happened with Mike. He helped me, pushed me, gave me work-for no damned reason other than he is, again, a selfless angel. Where does that combination of literary eloquence and charity come from? He tells me that he just likes to help people, especially writers.

Tina Brown, who works harder than almost anyone, was also one of the most supportive editors I have ever known. Working with her, for her, was an extraordinary experience-she was the best, for so many reasons. Tom Watson, a dear friend, is the paradigm of calm, good cheer, and eloquence. $\mathrm{He}$ is editor as artist-seamless, seemingly effortless, and simply astounding at turning ordinary material into something you might want to read. From inception to final product, Tom seemed solely motivated by how to make the story better, how to protect you from yourself, how to make your work shine.

Mike Nahrstedt gave me direction, hope and a free rein. He challenged me and didn't blink when I went into full high-opera mode. He gave me a long leash and made my work so much better. I would like to thank Tracy Dahlby, the director of the School of Journalism at the University of Texas at Austin-he is a fellow traveler in journalism, someone I felt an instant kinship with, someone who possesses a great mind and wit. He is a journalist through and through — and the future of that craft is secure under his careful, thoughtful stewardship. Also at the University of Texas, Roderick Hart, dean of the College of Communication, and Lorraine Branham, former director of the School of Journalism, were beyond supportive- they had faith in me, and for that I am forever grateful.

Jon Karp is a genius, and I am not sure how the hell I ever entered his orbit—but I am glad he let me in. I am grateful to have had him as an editor. 
The same extends to Rene Alegria—so humane, so kind, so supportive. There are many other journalists, friends: John Branch (one of the greatest editorial cartoonists in the history of that profession - and one of the most damned loyal friends anyone can ask for), Louie Canelakes, John Wilburn, Randy Eli Grothe, Bill Lodge, David Leeson, Christine Wicker, Anita Creamer, Mike Maza, Waltrina Stovall, Steve Ueckert, Bob Compton, Lorenzo Thomas, Earlie Hudnall, R. L. Griffin, David Maraniss, James Lee Burke, Buzz Bissinger, Mario Puzo, Scotty Ferris, Gail Sheehy, Sir Harold Evans, Dan Rather, Chuck Nevitt, Patrick Beach, Brad Buchholz, Peter Osnos, Steve Levin, Ellen Kampinsky, Jeff Franks, John Burnett, Rob Tomsho, Ross Ramsey, Dick Tarpley, Laura Jacobus, Buster Haas, Claudia Feldman, Harriet Blake, and many more.

Allison Faust and Theresa May at the University of Texas Press are offered my endless thanks for giving me the benefit of their extraordinary guidance and counsel. As with the other folks I have mentioned, they have the patience of saints and an innate humanity that tends to humble you. Many thanks to the brilliant copy editor Kip Keller; my respect and appreciation to the kind and masterful manuscript editor Lynne Chapman. All the staff members at the University of Texas Press must be thanked. They are treasures.

Rose and Nicholas are certitudes, among the only things in my life that have ever really been perfectly clear and holy. Holly Williams has watched over me (sometimes with alarm) and caught me over and over again.

She knows more about the way I turned, too often I suppose, onto the unlit road. 


\section{IN SEARCH OF THE BLUES}




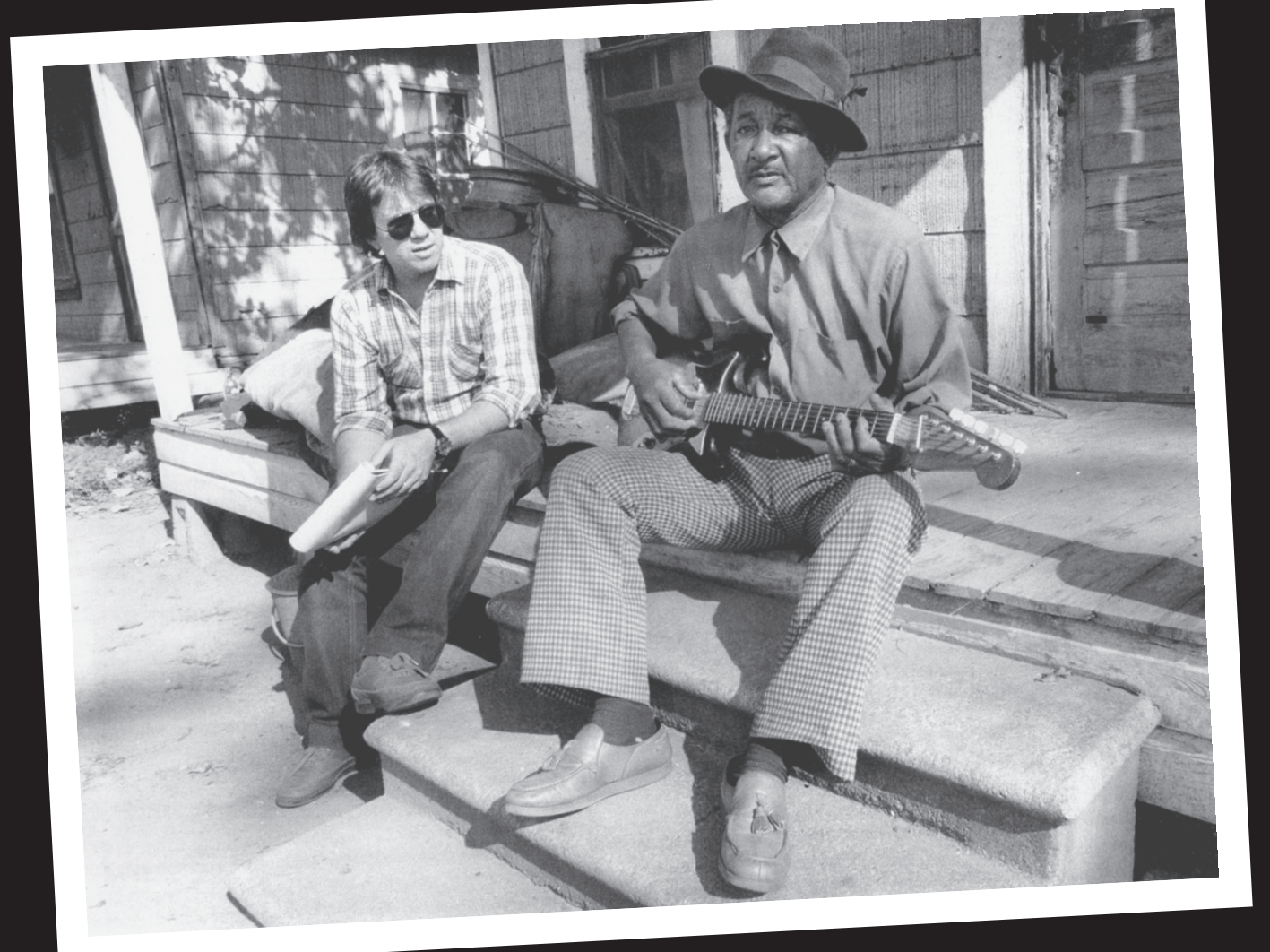

The author and blues musician Joe Cooper, 1985. Photo by Randy Eli Grothe. 